\title{
ASPECTUAL AND DISCOURSE-PRAGMATIC PROPERTIES OF VERBAL FORMS EXPRESSING SIMULTANEITY IN THREE FINNO-UGRIC LANGUAGES
}

\author{
Nikita Muravyev \\ National Research University Higher School of Economics, \\ Moscow
}

\begin{abstract}
This paper concerns the converb forms expressing simultaneity in Izhma Komi, Northern Khanty and Moksha belonging to the Finno-Ugric group of languages. The existing typological classifications of temporal relations and simultaneity relations in particular either are not detailed enough or lack rigorous criteria and thus appear not to be sufficient for understanding the usage and the distribution of temporal converbs. This study attempts to build a more detailed typological classification of simultaneity relations which accounts for the data of the languages under consideration. The analyzed parameters of variation include the viewpoint aspect of the events, clause modification type, givenness of the conveyed information and the pragmatic type of the predicate. Special attention is paid to the discourse-pragmatic properties of the forms which bring new insights into the discussion.
\end{abstract}

Keywords: converb, temporal relations, simultaneity, aspect, discourse, Izhma Komi, Moksha, Northern Khanty

DOI: https://doi.org/10.12697/jeful.2018.9.1.04

\section{Introduction}

Finno-Ugric languages have a wide variety of non-finite verb forms (participles, converbs, action nominals) that can be used in adverbial constructions denoting various circumstantial relations between the events (e.g. time, cause, condition, concession). The vast majority of adverbial forms describe temporal relations such as simultaneity, anteriority, posteriority and some finer semantic distinctions. These relations are often expressed by means of more than one form and one form can express more than one relation. This study takes a closer look at polysemy and competition of these forms, and some properties that determine their usage. 
There is currently little known about semantic and discourse-pragmatic variation of the converb forms. Some relevant observations can be found in a cross-linguistic study of converb forms by I. Nedjalkov (1998) as well as in the studies on the typology of converbs (Haspelmath and König 1995) and the typology of temporal constructions by Xrakovskij (2009). For instance, König (1995: 73-85), in discussing factors which influence semantic interpretation lists aspectual properties of the events, the order of the main and the dependent clause, operator scope, intonation etc. Although these factors have never received detailed typological consideration, there exist a number of studies on individual languages such as Onishi (1994: 468-476) on Motuna, Lehmann (1989: 267) on Tamil, and Pazel'skaja and Šluinskij (2007) on Mishar Tatar; see also the discussion of Finno-Ugric data by Čeremisina and Solovar (1991), Ylikoski (2001), and Nekrasova (2015). This article presents an attempt to build a typologically oriented classification of simultaneity subtypes and converb forms used in these functions which accounts not only for semantic but also for discourse-pragmatic parameters of variation.

The Moksha data used for this research were collected during fieldwork in the villages of Lesnoe Tsibaevo and Lesnoe Ardaševo in the Mordvin Republic (2013-2015). Izhma Komi and Northern Khanty data were collected in the villages of Muzhi, Vosyakhovo, and Ovgort in the Yamal-Nenets Autonomous Region $(2016,2017)$. All the data have come from elicitation.

Section 2 of the article presents an overview of the existing classification of simultaneity relations and sets the framework for further analysis and discussion. Section 3 contains a short morphological and semantic description of the relevant forms in the languages under consideration. Section 4 presents the data on the relevant semantic and pragmatic properties of the forms, followed by Section 5 with results of the study and discussion.

\section{Simultaneity and its subtypes}

Temporal constructions as a subject of study lies at the intersection of the semantic domain of temporal relations between events and the formal domain of complex sentences. It is usually agreed that the main clause event in a complex sentence serves as a temporal reference point for a dependent clause event, which can take place before the reference point (Anteriority), after the reference point (Posteriority) or coincide 
with it (Simultaneity). There have been several attempts at classifying the subtypes of these core relations (e.g. Kortmann 1998 and Xrakovskij 2009). Kortmann's classification (1998: 364-368), based on broad data of various means of adverbial subordination across Europe, is by far the most detailed and lists the following three subtypes of simultaneity:

- Simultaneity Overlap: p overlaps with q ('when');

- Simultaneity Duration: p opens up a time interval for the whole or part(s) of which q is true ('while');

- Simultaneity Co-Extensiveness: $\mathrm{p}$ opens up a time interval for the whole of which q is true ('as long as').

As one can see from the definitions, this subdivision is based on two semantic parameters: the presence of a time interval, which makes a temporal relation more precise (second and third relation as opposed to the first), and coverage of this interval by the second event (third relation as opposed to the second).

Xrakovskij (2009: 30) also distinguishes among three subtypes of simultaneity:

- Full Simultaneity, as in 'When Peter was working, Mary was reading a book';

- Partial Simultaneity I, as in 'When Peter was working, Mary entered the room';

- Partial Simultaneity II, as in 'When Mary entered the room, Peter was working'.

This classification accounts only for the mutual coverage of the events on the time axis. Here Full Simultaneity roughly matches Kortmann's full instance of Simultaneity Duration, whereas the other two relations correspond to the partial instance of Simultaneity Duration or the Simultaneity Overlap relation. It should be noted that the full simultaneity relation, unlike Kortmann's Simultaneity Co-Extensiveness, does not require that the two events be of the same length and have the same temporal boundaries, but rather that both be viewed as events extended in time with a coinciding intermediate part.

A remarkable feature of this model is that it is based on the viewpoint of the events which allows us to view a temporal relation as emergent from the aspectual characteristics of the corresponding predicates rather than assuming abstract time intervals as suggested by Kortmann. Thus, while the first relation is a result of combining two imperfective events, the second and the third relations result from combining an imperfective event with a perfective event. 
One more semantic classification by Nedjalkov (1998: 432) focuses on the ways of expressing adverbial relations and their subtypes in converb forms. All forms are classified according to whether they express only one relation (specialized) or multiple relations (contextual), the relation of one semantic domain (taxis, i.e. the temporal relation between the two events, and non-taxis) or relations from more than one semantic domain (mixed). Forms expressing Simultaneity fall into three classes: contextual mixed converbs, contextual taxis converbs and specialized taxis converbs, resulting in the following subtypes:

- Mixed converbs of Contextual Simultaneity, expressing Simultaneity proper, Accompanying Circumstance, Contact Anteriority, Manner, Instrument/Means, Condition and/or Cause;

- Contextual taxis converbs of Simultaneity and Anteriority;

- Specialized taxis converbs of Exact Simultaneity.

Here simultaneity has only two subtypes: Simultaneity (proper) and Exact Simultaneity. The former appears to be a neutral simultaneous relation while the latter is described by Nedjalkov as an 'exact coincidence' relation between the two events (Nedjalkov 1998: 440), which seemingly corresponds to Kortmann's distinction between Simultaneity Overlap and Simultaneity Duration, but additionally points at the contextual dependence and therefore vagueness of the former kind of relation.

This classification shows that, apart from Simultaneity itself, simultaneous converbs also express Attendant Circumstance (cf. König 1995: 65-66), which is not usually counted among the temporal relations but appears to be a special pragmatic variation of the Simultaneity relation, as in The boy walks singing, where the boldfaced part marks the new information, in comparison to The boy sings while walking, where the boldfaced part marks given information. Attendant Circumstance, as noted by König (1995: 65), should not be confused with Manner, as in The boy walks stumbling, which is a special instance of the former relation describing 'two aspects or dimensions of one event', rather than two separate events and thus not strictly being a temporal relation.

As we can see, all the above classifications share the idea that the simultaneous relations vary in degree of precision. In Kortmann's model, this opposition is formalized through the presence/absence of a time interval, whereas in Xrakovskij's model it is accounted for with the perfective/imperfective viewpoint distinction and in Nedjalkov's model it is viewed rather from the perspective of vagueness/concreteness of the Simultaneity meaning. In this paper, the meaning of the 
converb forms will first be described in Kortmann's terms, which seem to be the most convenient as a starting point for a description. Further on, these forms will be approached in general terms of precision but based on the perfective/imperfective opposition, as in Xrakovskij's work (2009). Apart from the aspectual dimension, another, discoursepragmatic dimension will be added to the analysis to account for the above-mentioned Attendant Circumstance relation.

\section{Functions of the simultaneous converbs}

The inventory of the verbal forms expressing Simultaneity in Moksha includes the converb forms in -əmsta, -amək and -əz'. The converb in -əmsta (cf. Koljadënkov 1962: 324, and Serebrennikov 1967: 216) presented in (1) expresses Simultaneity Duration and is historically an Elative case form of the verbal noun with possessive subject agreement markers.

\section{(1) Moksha}

mon' mol'-əm-sta-n son jarca-s'

I.OBL go-vN-ELA-POSS.1SG (s)he eat-PST.3sG

'While I was walking, he was eating.'

Moksha has two simple monomorphemic converb forms in -əmək and -əz' (cf. Koljadënkov 1962: 225-226 and Cygankin 1980: 357-362). The converb in -amək presented in (2) expresses Simultaneity Overlap/Contact Anteriority. Despite the absence of subject agreement morphology, it can be used not only in same-subject but also in different-subject contexts, as in (3).

(2) Moksha

s'oran'-əs' ivac' van-əmək langə-zo-n

boy-DEF shout.PST.3SG look-CVB top-ILL-POSS.1sG

'The boy was shouting when he looked at me.'

'The boy shouted after having looked at me.'

(3) Moksha

l'uka-mək šufc' tarad s'in'd'-əv-s'

sway-CVB tree.DEF branch break-PASS-PST.3SG

'When the tree swayed, its branch broke.' 
The other simple converb form - $-\partial z^{\prime}$ is same-subject only and expresses the relation of Attendant Circumstance (4) and Manner (5).

(4) Moksha

s'oran'-əs' ivac' langə-zə-n van-əz'

boy-DEF shout.PST.3SG top-ILL-POSS.1sG look-CVB.ATTC

'The boy was shouting and looking at me at the same time.'

(5) Moksha

pet'a ul'c'a-vo mol'-s' pupar' $\varepsilon-z$ '

Pete road-PROL go-PST.3SG stumble-CVB.ATTC

'Pete went along the road stumbling.'

Izhma Komi has at least the following four converbs denoting simultaneous relations between events: -iga-/-igen, -igmoz and -igtir (see Lytkin 1955: 244-245, Saxarova and Sel'kov 1976: 101-102, and Birjuk et al. 2010: 431-433), all diachronically related to the verbal noun in *-ig. The first form expresses the relation of Simultaneity Duration and is derived by means of the instrumental case marker or the possessive marked Inessive case respectively, see (6) below.

(6) Izhma Komi

tuj kuz'a mun-igen / mun-iga-s sia kized-is

road along go-CVB.INS / go-CVB.INE.POSs.3sg (s)he cough-PST.3sG

'While going along the road he coughed.'

The converb forms -igmoz and -igtir presented in (7) are diachronically verbal noun and adposition compounds. The former converb can express Simultaneity Duration or Attendant Circumstance/Manner, whereas the latter expresses only the relation of Attendant Circumstance/Manner.

(7) Izhma Komi

tuj kuz'a mun-igmoz / mun-igtir sia kized-is

road along go-CVB.SMLT / go-CVB.ATTC (s)he cough-PST.3sG

'He coughed, going (meanwhile) along the road.'

Northern Khanty expresses Simultaneity by means of the following three converb forms: $-m-\partial n,-t-\partial n$ and -man. The first two forms (cf. 
Čeremisina and Solovar 1991: 758-759, Nikolaeva 1995: 145, and Val'gamova et al. 2011: 180) are possessive-locative forms of the perfective participle in - $m$ and the imperfective participle in $-t$. A simple converb in -man (cf. Čeremisina and Solovar 1991: 761, Nikolaeva 1995: 146, 147, and Val'gamova et al. 2011: 182) is synchronically a monomorphemic same-subject form. The converb forms - $m$-ən (8) and -man (9) express the relation of Simultaneity Overlap/Contact Anteriority and -man additionally expresses the relation of Attendant Circumstance/Manner.

(8) Northern Khanty (Šuryškary dialect)

tuw tajam-ət pon-m-at-ən măn-əs

(s)he axe-3sg put-PFV.PTCP-3SG-LOC go-PST.3sG

'Putting down the axe he left.'

'Having put down the axe he left.'

(9) Northern Khanty (Šuryškary dialect)

luw tajam-ət pon-man măn-əs

(s)he axe-3sg put-cvi go-PST.3sg

'Putting down the axe he left.'

'Having put down the axe he left.'

The converb in -t-an, as shown below in (10), expresses the relation of Simultaneity Duration.

(10) Northern Khanty (Šuryškary dialect)

ma xotxar toxat-t-em-on joxt-ss pox-em

I floor wash-IPFV.PTCP-1SG-LOC come-PST.3SG boy-1SG

'While I was washing the floor, my son came.'

The existence of more than one form expressing a simultaneous relation between events in one language appears to be not merely a matter of language redundancy; each form has its own distinct semantic and pragmatic properties, which will be discussed in the following section of the paper. 


\section{Converb types and parameters of variation}

As stated in Section 2, there are two dimensions in which we may consider the simultaneous relation: a semantic dimension and a discourse-pragmatic dimension. From a semantic perspective, converb systems of the languages in question display a distinct encoding of Simultaneity Overlap or Contact Anteriority relation, which will henceforth be called Approximate Simultaneity, and the Simultaneity Duration relation, which will henceforth be called Precise Simultaneity. This distinction appears to be purely aspectual in nature and can be defined in terms of the acceptability of the event viewpoints for both events in a sentence (Section 4.1). The definitions of both types are as follows:

- Converbs expressing Approximate Simultaneity have no aspectual restrictions;

- Converbs expressing Precise Simultaneity require at least one event to be imperfective.

From a discourse-pragmatic perspective, both above-mentioned relations stand in opposition to the Attendant Circumstance relation. The former relations will be referred to as Background Simultaneity relations and the latter will be referred to as Descriptive Simultaneity relations. This dimension, however, may be more complex depending on at least the following three factors: clause modification type, givenness of the dependent event and pragmatic type of the predicates. Clausemodification type specifies the relation of the dependent clause to the main clause and to the context of the utterance and has two values: clause-external and clause-internal (for further details, see Section 4.2 below). The factor of dependent event givenness distinguishes between given, or activated information, and new, or not yet activated information (see Section 4.3). The last factor distinguishes the predicates which set a frame (i.e. which presuppose a certain time, duration, location, orientation, etc.) from those which do not (see Section 4.4). Summarizing the effect of these factors gives us the following distribution of converb forms:

- Converbs expressing Background Simultaneity require the clauseexternal modification type, given information in the dependent clause, and preferably a frame-setting dependent event;

- Converbs expressing Descriptive Simultaneity require the clauseinternal modification type, new information in the dependent clause and preferably a non-frame-setting dependent event. 


\subsection{Viewpoint of the events}

Event viewpoint, as noted inter alia, by Nedjalkov (1998: 447) and Xrakovskij (2009: 31-34) is an important parameter of semantic variation that specifies the temporal reference of the form. When at least the dependent event is imperfective, these events are always precisely simultaneous. Considering Klein's classic model of aspect (1994: 4) ${ }^{1}$, this happens because imperfective viewpoint is understood as the topic time containing an intermediate fragment of an event, so any other event within the same topic time cannot stop before or start after the given event.

In modern linguistic theory, there is a strong tradition of analyzing the viewpoint of an event as a sentential property resulting from an aspectual composition combining the aspectual class of the predicate with the properties of its participants, the lexical elements of temporalaspectual semantics, and the meaning of the tense-aspect grammatical categories (e.g. Dowty 1977, Krifka 1989). The obvious case of an imperfective event is an event described by a predicate with a salient or even the only possible atelic reading such as Vendlerian activities like 'eat' in (11), or 'scold' in (12), and states like 'sit' in (13). Such events set the context for a Precise Simultaneity relation and are compatible with any of the simultaneous converb forms in the three languages.

(11) Northern Khanty (Šuryškary dialect)

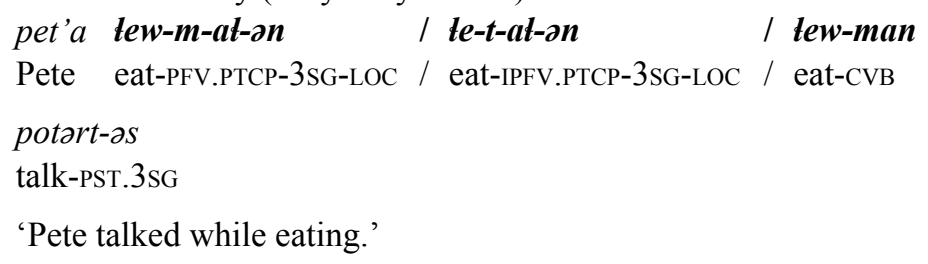

(12) Moksha

s'uc'-om-sto / s'uc'-oz' s'ora-nc son ivac' scold-vN-ELA / scold-CVB.ATTC son-POss.3sG.GEN (s)he shout.PST.3sG

'She shouted (while) scolding her son.'

1 In Klein's (1994: 4) model the temporal meaning is construed on the basis of a) speech time, b) reference time, c) situation time (the whole event) and d) topic time (its relevant part in the utterance). 
(13) Izhma Komi

kerka-in pukal-igen / pukal-igmoz / pukal-igtir gazeta

house-INE sit-CVB.INS / sit-CVB.SMLT / sit-CVB.ATTC newspaper

lid'd'-is

read-PST.3SG

'While sitting at home he read a newspaper.'

The prototypical perfective event, in turn, is described by a predicate with a salient or the only possible telic reading such as achievement verbs like 'shout (once)' in (14), (16), 'find' in (15), and 'fall' in (17)(19) below. As these examples show, the majority of forms in question appear to be ungrammatical with this category of events.

For instance, if a perfective dependent event is combined with an imperfective main event which also produces the Exact Simultaneity relation, the only acceptable forms are the Khanty - $m$-ən converb in (14), and the Moksha -amsta converb in (15).

(14) Northern Khanty (Šuryškary dialect)

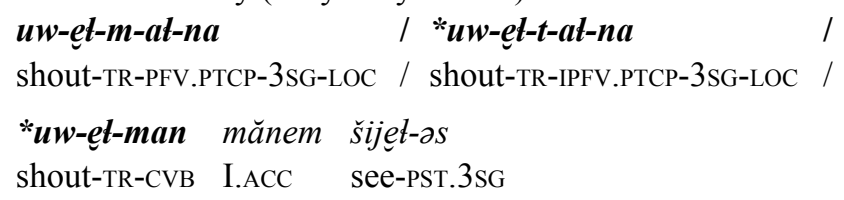

'When he shouted, he was looking at me.'

(15) Moksha

kn'iga-t' $\quad \boldsymbol{m u}$-m-sto / *mu-z' son korta-s'

book-DEF.SG.GEN find-vN-ELA / find-CVB.ATTC (s)he talk-PST.3sG

mart-an

with-POSS.1SG

'When he found the book, he was talking to me.'

(16) Izhma Komi

$\begin{array}{ll}\text { *gored-igen / } & \text { *gored-igmoz / *gored-igtir sia me } \\ \text { shout-CVB.INS / } & \text { shout-CVB.SMLT / shout-CVB.ATTC (s)he I } \\ \text { vil-am } & \text { vid'ed-is } \\ \text { top-INE.POSS.1SG } & \text { look-PST.3SG } \\ \text { 'When he shouted (once), he was looking at me.' }\end{array}$


If both events are perfective, the topic time includes these events in their entirety, so they may not only coincide but also take place in a sequence which can be described as an Approximate Simultaneity relation. A possibility of a non-simultaneous reading can be seen in pragmatically restricted contexts when the two events cannot actually coincide with one another. This is the case for the - $m$ - $2 n$ and -man forms in Khanty which mark a precedent perfective event 'fall' in the example (17) below, whereas the $-t-\partial n$ form is devoid of such an interpretation.

(17) Northern Khanty (Šuryškary dialect)

łons'-a răkən-m-em-na / răkən-man /
snow-DAT fall-PFV.PTCP-1SG-LOC / fall-CVB /
*răkən-t-em-na nox tot-s-əm
fall-IPFV.PTCP-1SG-LOC up stand-PST-1SG
'Having fallen in the snow, I got up.'

Only the -mak form of all the converbs in Moksha is compatible with consecutive perfective events, cf. (18) and (19) below.

(18) Moksha

$$
\begin{array}{llll}
\text { pra-mak } & \text { lov-t'i } & v i s ̌ k-s t \partial & s t^{\prime} \varepsilon-n \\
\text { fall-CVB } & \text { snow-DEF.SG.DAT } & \text { quick-ADV } & \text { stand-PST.1SG }
\end{array}
$$

'Having fallen in the snow, I quickly got up.'

(19) Moksha

$$
\begin{aligned}
& \text { *lov-t'i pra-m-sto / pra-z' višk-sta st' } \varepsilon-n \text { ' } \\
& \text { snow-DEF.SG.DAT fall-vN-ELA / fall-CVB.ATTC quick-ADV stand-PST.1SG } \\
& \text { 'Having fallen in the snow, I quickly got up.' }
\end{aligned}
$$

As example (20) shows, neither of the converb forms in Izhma Komi is acceptable in contexts of this kind.

(20) Izhma Komi

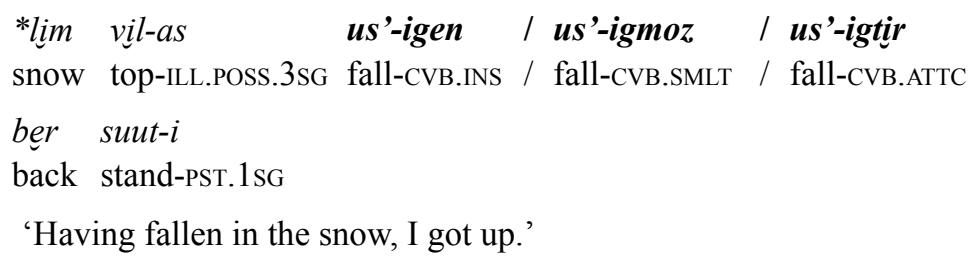


The above survey of possible viewpoint combinations for the converb forms in question reveals six Precise Simultaneity forms: - $t-\partial n$ (Khanty), -əmstz, -əz'(Moksha), -igX, -igmoz, -igtir (Komi), and three Approximate Simultaneity forms: -m-ən, -man (Khanty), and -əmək (Moksha). Most of the Precise Simultaneity forms allow only imperfective dependent events except -əmsta (along with an approximate - $m$-ən form) which also allow a rare combination of perfective dependent event and imperfective main event.

\subsection{Modification type of the dependent clause}

Another important parameter is the type of the modifying relation between the dependent clause and the main clause. Numerous studies in clause-linkage distinguish between the background and the foreground type of an adverbial clause (Givón 2001, Thompson et al. 2007, Lehmann 1988). Clauses of the former type, which will be labelled here as external-modifying following Dooley (2010: 10), as the English purpose clause in (21a) below, are used for establishing links to the global discourse context whereas clauses of the latter type, internalmodifying, as in (21d), relate only to the main clause itself. Superficially, these two types of clauses have different preferences in the mutual order of the main clause and the dependent clause (Givón 2001: 334, Dooley 2010: 10). External-modifying clauses tend to occupy the sentence-initial, or topical, position while internal-modifying clauses usually occupy the sentence-final position or immediately precede the core of the clause (cf. ungrammaticality of the inverse order in $21 \mathrm{~b}, \mathrm{c}$ ).

(21) a. To illustrate this, consider the following passage (Givón 2001: 334).

b. *Consider the following passage to illustrate this (ibid.).

c. *To fix the plumbing then he went out (ibid.).

d. Then he went out to fix the plumbing (ibid.).

Yet, when it comes to temporal clauses, there appear to be fewer restrictions on the dependent clause placement. For example, 'when' -clauses, as in the English sentences $(22 \mathrm{a}, \mathrm{b})$ below, freely allow both a preposition and a postposition with little if any difference in the discourse relation.

(22) a. When Peter came, Mary left.

b. Mary left when Peter came. 
A more rigorous criterion for identifying the modification type is the operator scope, as suggested in Dooley (2010: 10). Internal-modifying clauses usually appear in the scope of illocutionary force and negative main clause operators while external-modifying clauses do not. This criterion has also been discussed in some language-particular descriptions (see for example Rappaport 1984: 113-116, Pazel'skaja and Šluinskij 2007: 56, and Maslova 2003: 374). Considering the sentence (23) below from Moksha and its negative counterparts in (24) and (25), the event of working marked with the converb forms in -amsta and $-\partial m a k$ retains its positive truth value under sentence negation and is thus outside the scope of negation, whereas the same event marked with the converb form $-\partial z$ ' changes its truth value to negative and accordingly falls in the scope of the negation with two possible readings: (a) negation of both events and (b) negation of the dependent event only, the latter more pragmatically odd but still possible.

(23) Moksha

al'e-z'ə mora-j rabota-m-sto / rabota-mok /

father-POss.1sG sing-NPST.3sg work-VN-ELA / work-CVB /

rabota-z'

work-CVB.ATTC

'Father sings (while) working.'

(24) Moksha

al'c-z's af mora-j rabota-m-sto / rabota-mok /

father-POss.1SG NEG sing-NPST.3SG work-VN-ELA / work-CVB /

\%rabota-z'

work-CVB.ATTC

'Father doesn't sing while working.'

(25) Moksha

al'e-z'o af mora-j rabota-z' / \%rabota-mok /

father-POSs.1sG NEG sing-NPST.3sG work-CVB.ATTC / work-CVB /

\%rabota-m-sto

work-VN-ELA

a) 'Father doesn't sing and work at the same time.'

b) ?'Father sings but at the same time doesn't work.' 
As examples (26-28) show, the same holds for the Komi converb form -iga-/-igen as opposed to the converb forms -igmoz and -igtir: the former stays outside the scope of the negative operator and the latter fall under the main clause negation.

(26) Izhma Komi

me s'ill-a rebit-igen / rebit-igmoz / rebit-igtị

I sing-NPST.1sg work-CVB.INS / work-CVB.SMLT / work-CVB.ATTC

'I sing (while) working.'

(27) Izhma Komi

me o-g s'ïi rẹbit-igen / \%rẹbit-igmoz / \%rẹbit-igtir

I NEG.NPST-1 sing work-CVB.INS / work-CVB.SMLT / work-CVB.ATTC

'I don't sing while working.'

(28) Izhma Komi

me o-g s'ị rẹbit-igmoz / rẹbit-igtir / \%rebit-igen

I NEG.NPST-1 sing work-CVB.SMLT / work-CVB.ATTC / work-CVB.INS

a) 'I don't sing working at the same time.'

b) ?'I sing but at the same time don't work.'

The distribution of the converb forms in Northern Khanty in this respect is slightly different. As one can see from (29) and (30), both forms mark the event 'work', which stays outside the scope of negation.

(29) Northern Khanty (Middle-Ob dialect)

as'-em ropit-m-at-ən / ropit-man ari-j-əs

father-1SG work-PFV.PTCP-3SG-LOC / work-CVB sing-ST-PST.3sG

'My father sang while working.'

(30) Northern Khanty (Middle-Ob dialect)

as'-em ropit-m-at-on / ropit-man ăt ari-j-əs

father-1sG work-PFV.PTCP-3SG-LOC / work-CVB NEG sing-ST-PST.3sG

'My father did not sing while working.'

Yet, in case of -man, if the main event is described by a framesetting predicate (see the next section) for the dependent event, then the dependent event, such as 'sing' in (31), can also fall under the sentence negation. 
(31) Northern Khanty (Middle-Ob dialect) tuoxs-at ăt măn-s-ət juoš xuwat ari-man friend-PL NEG go-PST-3PL road along sing-CVB

a) 'The friends did not go along the road singing.'

b) 'The friends went along the road without singing.'

As we can see, the negation scope test appears to be relatively strong in distinguishing internal-modifying converbs from external-modifying converbs, with the -man form as the only exception displaying an intermediate behaviour.

\subsection{Givenness of the dependent clause}

One more parameter which has not been mentioned in discussions of the pragmatic properties of the converbs, but is associated with the modification type and also seems to be relevant to this discussion, is the givenness of the information in the dependent clause. To adequately assess the state of the information in a sentence, one generally has to appeal to the context, in which this sentence is uttered, which involves analyzing corpus data and/or conducting an experiment. However, the sentence itself may contain certain clues which help identify the state of the information without knowing the context of the utterance.

Since converb clauses in Finno-Ugric languages morphologically and syntactically resemble noun phrases, one way of telling whether a clause contains a given piece of information is to see whether the head predicate in the clause allows possessive nominal markers in the anaphoric function relating to a salient referent in discourse. Possessive marking of the converb form encodes the person and the number of the dependent clause subject which itself can have an explicit (32) or zero expression with a different-subject (33) or a same-subject reference (34).

(32) Moksha

$\begin{array}{llll}\text { maša-n' } & \text { mol'-om-sto-nzo } & \text { mon } & \text { jarca- } n \\ \text { Mary-GEN } & \text { go-VN-ELA-POSS.3SG } & \text { I } & \text { eat-PST.1SG }\end{array}$

'While Mary was walking, I was eating.' 
(33) Moksha

mol'-am-sta-nzo mon jarca-n'

go-VN-ELA-POSS.3SG I eat-PST.1SG

'While she was walking, I was eating.'

(34) Moksha

mol'-om-sto-nzo son mora-s'

go-VN-ELA-POSS.3SG (s)he sing-PST.3SG

'While walking, she was singing.'

The second case appears to be the most illustrative of the abovementioned examples because the subject is not overtly mentioned and the zero expression is not coindexed with any noun phrase in the sentence, thus standing for some given referent in the discourse. The same option is available for the -iga-/-igen forms in Komi (35) as well as the $-m-\partial n$ and $-t-\partial n$ forms in Khanty (36).

(35) Izhma Komi

s'ill-iga-niss sia jẹkt-is

sing-CVB.INE-POSS3PL (s)he dance-PST.3SG

'While they were singing he was dancing.'

(36) Northern Khanty (Šuryškary dialect)

manem šijolo-m-at-na uw-att-s-əm

I.ACC see-PFV.PTCP-3SG-LOC shout-CAUS-PST-1SG

'When he saw me I shouted.'

In Izhma Komi the third person singular possessive marker, as can be seen in (37) below, has grammaticalized into a definiteness marker (cf. Kaškin and Pankova 2011).

(37) Izhma Komi

eta kerka-as

this house-INE.POSS.3SG

'In this house.'

A striking consequence of this fact is that the new function of this marker can be transferred onto its use with the converb form in -iga/-igen which can be clearly seen in cases like (38) where, despite the 
actual co-reference between the two subjects, the predicate forms have different person markings.

(38) Izhma Komi

$$
\begin{array}{llll}
\text { pizan } & \text { saj-in pukal-iga-s } & \text { me šid } & \text { s'o-i } \\
\text { table back-INE } & \text { sit-CVB.INE-POSS3SG I } & \text { soup } & \text { eat-PST.1SG } \\
\text { 'While sitting at the table I ate the soup.' }
\end{array}
$$

Converb forms with same-subject reference, namely the converbs $-\partial z$ ', -igtir and -man, have no morphological means for referring to the external context. This observation, supported by the internal-modifying function of these forms (see the previous section), can be regarded as evidence for the new-only state of information in the corresponding converb clauses. One exception is the Komi form in -igmoz, as in (39), which, despite its same-subjectness, attaches a possessive marking which can have not only an internal (i.e. to the main clause subject) but, in addition, also an external (i.e. to some referent in the context) reference.

(39) Izhma Komi

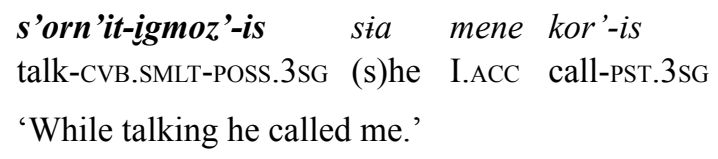

'While talking he called me.'

Another, though less straightforward, way to determine the activation state of the dependent clause is to see whether it allows definite argument marking. For instance, Moksha has a DOM system in which indefinite direct objects are unmarked (40a) and definite direct objects receive definite genitive marking (40b).

(40) Moksha

a. son n'cj-s' tarelka

(s)he see-PST.3sG plate-DEF.GEN

'He saw a plate.'

b. son n'cj-əz'd tarelka-t'

(s)he see-PST.3SG.OBJ:SG plate-DEF.GEN

'He saw the plate.' 
In converb clauses, -əmək and -əmstə converbs allow both indefinite and definite object marking, which proves their ability to convey the given information. The former converb retains the finite unmarked form vs. definite genitive pattern (41) while the latter substitutes the unmarked form with the indefinite genitive, which is more common for non-finite clauses (42).

(41) Moksha

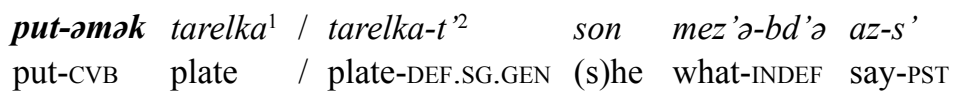

'While putting down $\mathrm{a}^{1 /} / \mathrm{the}^{2}$ plate he said something.'

(42) Moksha

tarelka- $n^{\prime 1}$ / tarelka-t ${ }^{\prime 2} \quad$ put-əm-sto son mez'ə-bd'ə az-s'

plate-GEN / plate-DEF.SG.GEN put-VN-ELA (s)he what-INDEF say-PST

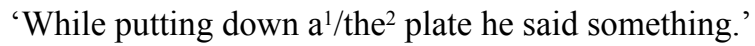

In comparison, the $-\partial z$ ' converb in (43) allows only the indefinite object marking which speaks in favour of the new-only state of information in the clause headed by this form.

(43) Moksha

$$
\begin{aligned}
& \text { tarelka-n' / *tarelka-t' put-oz', son mez's-bd's az-s' } \\
& \text { plate-GEN / plate-DEF.SG.GEN put-CVB.ATTC (s)he what-INDEF say-PST } \\
& \text { 'Putting down a plate he said something.' }
\end{aligned}
$$

The same holds for the Komi -igtir form which in comparison to -iga-/-igen and -igmoz converbs cannot take direct objects with the definite marking, as shown in (44).

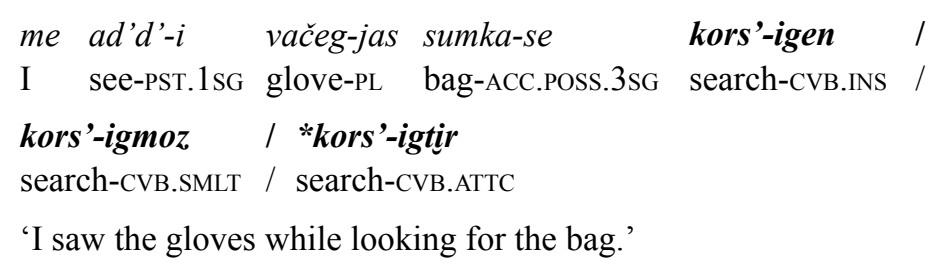

The above examples show that all three languages have converb forms which allow different-subject reference along with anaphoric possessive or definite marking on the predicate or on the direct object 
and thus can convey given information. At the same time, there are forms with same-subject only reference which, except for the Komi -igmoz form, do not attach person-number marking on the predicate and do not take definite objects and thus convey new information.

\subsection{Pragmatic type of the dependent event}

Another parameter comes from comparing the relations of Simultaneity and Attendant Circumstance, which König (1995: 70) has explored. Discussing the differences between these relations, König mentions the idea that converbs expressing the former relation tend to mark events which have a conventional time frame, i.e. some pragmatically associated knowledge about their natural time and/or duration. Generally speaking, this frame may include any knowledge inferred from the context or from world knowledge such as other kinds of circumstances, common sets of participants, or associated events. For instance, uttering a simple sentence like Peter left with a polyvalent predicate to leave presupposes some information at least about Peter's initial location and direction of motion but possibly also about purpose, time, preceding events, etc. By contrast, the sentence Peter smiled with a monovalent predicate to smile does not set any such frame rather describing some state or property of Peter. Thus, an obvious way to test this hypothesis is to construct a pair of events, one being a frame-setting event and the other not. The most evident examples of such paired events are events which pragmatically include each other such as 'sleep' + 'snore', 'wash' + 'soap', 'eat' + 'chew' (frame-setting events are marked with italics). As can be seen below, in Moksha the forms -əmstə and -əmək are compatible only with the first event of a pair as 'sleep' in (45) below and the $-\partial z$ ' form only with the second as 'snore' in (46).

(45) Moksha

son ud-əm-sto / ud-əmək / *ud-əz'
he sleep-VN-ELA / sleep-CVB / sleep-CVB.ATTC
'He snore-PST.3SG
snored while sleeping.'

(46) Moksha
son ud-as'
karna-z,
/ *karna-m-sto
/ *karna-mok
he sleep-PST.3sG
snore-CVB.ATTC / snore-VN-ELA / snore-CVB
'He slept snoring.' 
Some converb forms show intermediate behaviour in that they are pragmatically compatible with either of the two events in a pair. For example, while the Khanty - $m$-ən form (as well as $-t-2 n$ ) marks only the frame-setting event, the -man form appears to be equally suitable in both contexts (cf. examples 47 and 48).

(47) Northern Khanty (Šuryškary dialect)

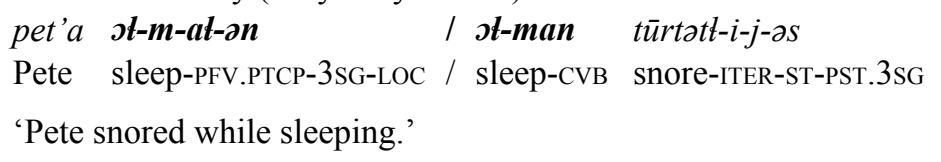

(48) Northern Khanty (Šuryškary dialect)

tūrtott-i-man / 'türtott-i-m-at-on pet'a st-as

snore-ITER-CVB / snore-PFV.PTCP-3SG-LOC Pete sleep-PST.3sG

'Pete slept snoring.'

Komi converbs display all three kinds of behaviour in this context (49), (50). The converb in -iga-/-igen is used with frame-setting events, the converb form -igtir appears, on the contrary, with forms that do not set a frame, and the converb form -igmoz appears with both.

(49) Izhma Komi
sịa uz'-igen
/ uz'-igmoz
/ *uz'-igtir
xorg-is
he sleep-cvB.INS / sleep-CVB.SMLt / sleep-cvB.ATTC snore-PST.3sG
'He snored while sleeping.'

(50) Izhma Komi

sia $u z$ '-is xorg-igmoz / xorg-igtir / *xorg-igen

he sleep-PST.3sg snore-CVB.SMLt / snore-CVB.ATTC / snore-CVB.INS

'He slept snoring.'

As the above examples show, the results of the paired event test almost exactly correspond to the data on the scope of negation from the previous section. The only form with a special behaviour is the Komi converb form -igmoz which appears indifferent to frame-setting, meanwhile always falling in the scope of the sentence negation.

Distribution of the converb forms with respect to the above-discussed parameters of variation is summed up in Table 1 below. 
Table 1: Possible viewpoint combinations of the events.

\begin{tabular}{l|c|c|c|c|c|c|c|c|c} 
& \multicolumn{3}{|c|}{$\begin{array}{c}\text { Northern } \\
\text { Khanty }\end{array}$} & \multicolumn{3}{c|}{ Moksha } & \multicolumn{3}{c}{ Izhma Komi } \\
& mon & ton & man & omsto & omok & oz' & iga & igmoz & igtir \\
\hline $\begin{array}{l}\text { Precise (P), } \\
\begin{array}{l}\text { Approximate (A) } \\
\text { Simultaneity } \\
\text { relation }\end{array}\end{array}$ & A & P & A & P & A & P & P & P & P \\
\hline $\begin{array}{l}\text { Background (B), } \\
\begin{array}{l}\text { Descriptive (D) } \\
\text { relation, } \\
\text { neutral (N) }\end{array}\end{array}$ & $\mathrm{B}$ & $\mathrm{B}$ & $\mathrm{N}$ & $\mathrm{B}$ & $\mathrm{B}$ & $\mathrm{D}$ & $\mathrm{B}$ & $\mathrm{N}$ & $\mathrm{D}$ \\
\hline $\begin{array}{l}>\text { External } \\
\text { modification }\end{array}$ & + & + & $+/-$ & + & + & - & + & - & - \\
\hline $\begin{array}{l}>\text { Definite or } \\
\text { anaphoric posses- } \\
\text { sive marking }\end{array}$ & + & + & - & + & + & - & + & + & - \\
\hline $\begin{array}{l}>\text { Frame-setting } \\
\text { dependent event }\end{array}$ & + & + & $+/-$ & + & + & - & + & $+/-$ & - \\
\hline
\end{tabular}

\section{Results and discussion}

Comparative data on the distribution of the Simultaneity converbs show that the forms in question vary in function not only in their temporal and aspectual meaning but also in their discourse-pragmatic properties. The semantic type of the converb (Precise or Approximate Simultaneity) depends on whether it requires at least one imperfective event, mainly the dependent event, or allows also a combination of two perfective events. The discourse-pragmatic type (Background or Descriptive simultaneity) is identified based on the three parameters: modification type of the dependent clause, givenness of the dependent clause and the pragmatic type of the marked predicate. The intersection of all these parameter values results in a total of the following five subtypes, embracing all the logical combinations of the parameter values, except the value Approximate-descriptive, which has not been revealed by our data:

- Approximate-background Simultaneity: Khanty converb -m-ən, Moksha converb -əmək;

- Approximate-neutral Simultaneity: Khanty converb -man; 
- Precise-background Simultaneity: Khanty converb -t-an, Moksha converb -amsta, Komi converb -iga-/-igen;

- Precise-neutral Simultaneity: Komi converb -igmoz;

- Precise-descriptive Simultaneity: Moksha converb -əz', Komi converb -igtir.

The majority of the converb forms analysed relate to the Approximate- and Precise-background subtypes, reflecting Kortmann's opposition of the semantically vague Simultaneity Overlap relation and the more specific Simultaneity Duration relation. Adding the pragmatic dimension to the classification allows us to consider among the Simultaneity subtypes one more important temporal relation of Attendant Circumstance, or Precise-new Simultaneity as well as less common, pragmatically intermediate relations such as Approximate-neutral and Precise-neutral Simultaneity as a further elaboration on what is considered by Nedjalkov as 'Mixed converbs of contextual Simultaneity'.

The results of this paper can be applied to future studies of temporal clauses in other Uralic languages, as well as to broader typological research. They offer a number of new insights into the syntactic properties of the adverbial clauses, the interaction between converbs and the information structure of the sentence, and their functioning in the context of narration or in dialogue speech, which could provide a better understanding of the phenomena in question.

\section{Acknowledgments}

This research was conducted in terms of the project supported by Russian Science Foundation, grant No. 18-78-10128. I express my sincere gratitude to the communities of Moksha, Komi and Northern Khanty speakers in the villages of Lesnoe Tsibaevo and Lesnoe Ardaševo in the Mordvin Republic, as well as Muzhi, Vosyakhovo, and Ovgort in the Yamal-Nenets Autonomous Region for the possibility to conduct a fruitful fieldwork there in 2013-2015, 2016 and 2017. I am grateful to Egor Kashkin, Maria Kholodilova, Alexey Kozlov and Aigul Zakirova who participated in our field trips and with whom I have discussed much of the collected data. I also thank my anonymous reviewers and the editorial team of the current volume of ESUKA/ JEFUL who significantly helped me to improve the quality of this paper. Of course, all remaining mistakes are my own. 


\author{
Address \\ Nikita Muravyev \\ Vorotnikovsky per. 5/9-62, \\ 127006 Moscow, Russia \\ Email: nikita.muraviev@gmail.com
}

\title{
References
}

Birjuk, Ol'ga L., Egor V. Kaškin, Ariadna I. Kuznecova, and Maria N. Usačëva (2010) Slovar' muževskogo govora ižemskogo dialekta komi-zyrjanskogo jazyka. Ekaterinburg: Basko.

Čeremisina, Maria I. and Valentina N. Solovar (1991) 'Zalogovost', perexodnost', prjamoj ob"ekt v jazykax raznyx system". In Jazyki narodov Sibiri. Grammatičeskie issledovanija, 66-84. Novosibirsk: Nauka.

Cygankin, Dmitrij V., ed. (1980) Grammatika mordovskix jazykov. Fonetika. Grafika. Orfografija. Morfologija. Učebnik dlja nacional'nyx otdelenij vuzov. Saransk: Izd-vo Mordov. universiteta.

Dooley, Robert A. (2010) Exploring clause chaining. SIL Electronic Working Papers in Linguistics. Available online at

$<$ https://www.sil.org/resources/publications/entry/7858>. Accessed on 03.02.2018.

Dowty David R. (1977) "Towards a semantic analysis of verb aspect and the English 'imperfective' progressive”. Linguistics and philosophy 1, 45-77.

Givón, Talmy (2001) Syntax: an introduction. Vol. 2. Amsterdam: Benjamins.

Haspelmath, Martin and Ekkehard König, eds. (1995) Converbs in Cross-Linguistic Perspective. Berlin: Mouton de Gruyter.

Kaškin, Egor V. and Marina C. Pankova (2011) “Eksperimental'noe issledovanie upotrebleniia posessivnogo skloneniia $\mathrm{v}$ ižemskom dialekte komi-zyrianskogo iazyka". In Nikolaj N. Kazanskij, ed. Acta Linguistica Petropolitana. Vol. 7, part 3, 82-87. Saint Petersburg: Nauka.

Klein, Wolfgang (1994) Time in language. London, and New York: Routledge.

Koljadënkov, Mixajl N., ed. (1962) Grammatika mordovskix (mokšanskogo $i$ errjanskogo) jazykov. Čast' 1: Fonetika i morfologija. Saransk: Mordovskoe knižnoe izdatel'stvo.

König, Ekkehard (1995) "The meaning of converb constructions”. In Martin Haspelmath and Ekkehard König, eds. Converbs in cross-linguistic perspective, 57-96. Berlin: Mouton de Gruyter.

Kortmann, Bernd (1998) "Adverbial subordinators in the languages of Europe". In Johan van der Auwera and Dónall P. Ó Baoill, eds. Adverbial constructions in the languages of Europe, 457-562. (Empirical Approaches to Language Typology, 20-3.) Berlin: Mouton de Gruyter.

Krifka, Manfred (1989) "Nominal reference, temporal constitution and quantification in event semantics". In Renate Bartsch, Johan van Benthem, and Peter van Emde Boas, eds. Semantics and contextual expression, 75-115. Dordrecht: Foris Publications. 
Lehmann, Christian (1988) “Towards a typology of clause linkage". In John Haiman and Sandra A. Thompson, eds. Clause combining in grammar and discourse, 181-226. Amsterdam and Philadelphia: John Benjamins.

Lehmann, Thomas (1989) A grammar of modern Tamil. Pondicherry Institute of Linguistics and Culture.

Lytkin, Vasilij I. (1955) Sovremennyj komi jazyk, Chast' 1. Syktyvkar.

Maslova, Elena (2003) A grammar of Kolyma Yukaghir. Berlin, and New York: Mouton de Gruyter.

Nedjalkov, Igor P. (1998) "Converbs in the languages of Europe". In Johan van der Auwera and Dónall P. Ó Baoill, eds. Adverbial constructions in the languages of Europe, 421-455. (Empirical approaches to language typology, 20-3.) Berlin: Mouton de Gruyter.

Nekrasova, Ol'ga I. (2015) Deepričastnye konstrukcii v komi jazyke. Ph.D. dissertation. Iževsk.

Nikolaeva, Irina A. (1995) Obdorskij dialekt xantyjskogo jazyka. (Mitteilungen der Societas Uralo-Altaica, 15.) Hamburg: Finnisch-Ugrisches Seminar der Universität Hamburg.

Onishi, Masayuki (1994) A grammar of Motuna (Bougainville, Papua New Guinea). Australian National University.

Pazel'skaja, Anna G. and Andrej B. Šluinskij (2007) “Obstojatel'stvennye predloženija”. In Ekaterina A. Ljutikova, ed. Mišarskij dialekt tatarskogo jazyka. Očerki po sintaksisu i semantike, 38-82. Kazan': Magarif.

Rappaport, Gilbert C. (1984) Grammatical function and syntactic structure: The adverbial participle of Russian. (UCLA Slavic Studies, 9.) Columbus, $\mathrm{OH}$ : Slavica Publishers.

Saxarova, Marfa A. and Nikolaj N. Sel'kov (1976) Ižemskij dialekt komi jazyka. Syktyvkar: Komi knižnoe izdatel'stvo.

Serebrennikov, Boris A. (1967) Istoričeskaja morfologija mordovskix jazykov. Moskva: Nauka.

Thompson, Sandra A., Robert E. Longacre, and Shin Ja Hwang (2007) “Adverbial clauses". In Timothy Shopen, ed. Language typology and syntactic description: complex constructions. Vol. 2, 237-300. Cambridge: Cambridge University Press.

Val'gamova, Svetlana I., Natal'ja B. Koškareva, Sofija V. Onina, and Anastasija A. Šijanova (2011) Dialektologičeskij slovar'xantyjskogo jazyka (šuryškarskij $i$ priural'skij dialekty). Ekaterinburg: Basko.

Xrakovskij, Viktor S. (2009) “Taksis: semantika, sintaksis, tipologija”. In Viktor S. Xrakovskij, ed. Tipologija taksisnyx konstrukcij. Moskva: Znak.

Ylikoski, Jussi (2001) "Converbs in Finnish and Komi: differences and similarities". In Tõnu Seilenthal, ed. Congressus Nonus Internationalis Fenno-Ugristarum. Pars VI, 420-424. Tartu: Tartu University Publishers. 


\begin{abstract}
Аннотация. Никита Муравьев: Аспектуальные и дискурсивные свойства глагольных форм со значением одновременности в трёх финно-угорских языках. В данной статье рассматриваются формы деепричастий, выражающие семантику одновременности в коми-зырянском, хантыйском и мокшанском языках финно-угорской языковой группы. Существующие типологические классификации таксисных функций и, в частности, функций зоны одновременности представляются либо недостаточно проработанными, либо построенными на неочевидных критериях и поэтому не являются достаточными для понимания функционирования и дистрибуции таксисных деепричастий. Исследование представляет собой попытку построить типологически ориентированную классификацию функций одновременности, адекватно описывающую рассматриваемый языковой материал. В статье анализируются параметры видового ракурса ситуаций, типа клаузальной модификации, статуса активации информации и прагматического типа предиката. Особое внимание уделяется дискурсивным свойствам форм, которые открывают новые перспективы для исследования таксисных конструкций.
\end{abstract}

Ключевые слова: деепричастие, одновременность, аспект, дискурс, комизырянский язык, мокшанский язык, хантыйский язык

Kokkuvõte. Nikita Muravyev: Verbivormide aspektilised ja diskursuspragmaatilised omadused samaaegsuse väljendamiseks soome-ugri keeltes. Siinne artikkel käsitleb samaaegsust väljendavaid konverbivorme ižmakomi, põhjahandi ja mokša keeltes, mis kuuluvad soome-ugri keelerühma. Olemasolevad tööd, mis tüpoloogilisest vaatenurgast ajasuhteid ja samaaegsust käsitlevad on kas üldsõnalised või ei sisalda täpseid kriteeriume, mistõttu on nad ajaliste konverbide kasutuse ning distributsiooni mõistmiseks ebapiisavad. See uurimus püüab töös käsitletud keelte andmete põhjal anda detailsema tüpoloogilise klassifikatsiooni samaaegsuse suhetest. Analüüsitavad variatsiooniparameetrid hõlmavad situatsioonide vaatepunktiaspekti, lause modifikatsioonitüüpi, edastatava informatsiooni tuntust ja predikaadi pragmaatilist tüüpi. Erilist tähelepanu pööratakse arutelusse uusi vaatenurki andvate vormide diskursus-pragmaatilistele omadustele.

Märksõnad: konverb, ajasuhted, samaaegsus, aspekt, diskursus, ižmakomi, mokša, põhjahandi 